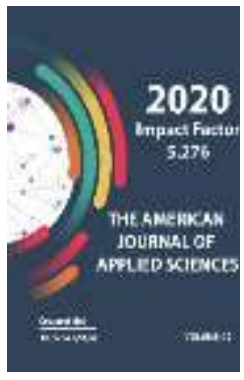

\section{THE WORK “AL-MUFASSAL FI SAN'ATI-L-I'ROB” BY MAHMUD ZAMAKHSHARI AND ITS LITHOGRAPY COPIES}

\author{
Nigora Askaralievna Sulaymonova \\ Candidate Of Philological Sciences, Associate Professor, Tashkent State University Of Uzbek \\ Language And Literature, Department Of Oriental Languages, Tashkent, Uzbekistan
}

Journal Website: http://usajournalshub.c om/index,php/tajas

Copyright: Original content from this work may be used under the terms of the creative commons attributes 4.0 licence.

\title{
ABSTRACT
}

The article is devoted to the history of how the work "al-Mufassal fi san'ati-l-i'rob" by Mahmud Zamakhshari, a Kwaresmian scholar, was written, its content and essence, also it provides information on copies of the work stored in Uzbekistan, in particular, in the fund at the Science Academy of Uzbekistan in Tashkent State Institute of Oriental Studies named after Abu Rayhan Biruni. Six manuscript copies and two lithography copies of the work in the fund have been analyzed from the point of view of source studies. As a result of the analysis, full bibliographic indicators of all copies of the work which exist at the fund have been formed.

\section{KEYWORDS}

Mahmud Zamakhshari, Kwaresmian scholar, the work “Mufassal”, linguistics, Arabic, Arab grammar, Arab letters, manuscript, lithography, inventory number.

\section{INTRODUCTION}

Mahmud Zamakhshari, a Kwaresmian great scholar who had become famous with his knowledge, intellectual abilities and rich heritage all around the world including the
East, exposed the secrets of Arabic grammar with its many challenges in one of his works devoted to linguistics "al-Mufassal fi san'ati-li'rob" (A Detailed Book on the Art of Flexion). 
According to the biographical sources of Mahmud Zamakhshari, he traveled in search of knowledge to the cities of the East, which were the centers of enlightenment at that time Khorasan, Isfahan, Baghdad, Hijaz, Hamadan, Damascus [1; 542-556]. One of such trips was the reason for the creation of the work "Mufassal". The scholar completed his work in one year and four months (1119-1121).

\section{MAIN PART}

Zamakhshari became actively involved in science while living in Mecca. In the process of observations, the scholar carefully studies the occupations, ways of speaking, and language features of even the smallest tribes living in the area, trying to determine the meaning and essence of each word. As a result, a set of rules of grammar of the Arabic language "Mufassal" was created. The full title of the work is "al-Mufassal fi san'ati-l-i'rob", and in some sources it is "al-Mufassal fi-n-nahv" [2;107]. This work has been recognized by leading linguists as an unprecedented discovery in Arabic grammar. Today, this work is one of the main textbooks on the grammar of the Arabic language in a number of prestigious universities in the Arab world. At present, students are taught Arabic grammar on the basis of this work at al-Azhar University in Cairo, Egypt.

This work differs from other works of the scholar on linguistics in that Zamakhshari abandoned in his "Mufassal" the traditional order in which other scholars described first syntax, then morphology, and then phonetics. The scholar solved grammatical problems by parts of speech, in other words, names (all words that have an independent meaning but do not have a tense: noun, adjective, number, pronoun, adverb), verb (words that are used to describe actions and have an tense), and letters (auxiliary words whose meaning is understood only when combined with other words which are not used separately: conjunction, interjection, determiners) [3;
239]. Each section explores both syntax and morphological issues. At the end of the work, phonetics is described.

"Mufassal", a major guide to the study of the nahw and sarf of the Arabic language, gained great attention among the Arabs at that time. According to orientalist Ubaydulla Uvatov, even the Arabs themselves acknowledged the scholar and his works in the field of Arabic linguistics, saying that "if this Chorasmian beardless and crippled man were not born, the Arabs would not have fully known their language." Muzaffariddin Musa, the ruler of Damascus in his time, promised to give 5,000 silver coins and presents to the person who memorized this work [4; 25-26]. This example alone shows that "Mufassal" is highly valued.

Many scholars acknowledge the importance of this work of Zamakhshari in terms of studying the Arabic language and claim that it is second only to the famous scholar Sibavayhi's "Kitabu Sibavayh", who lived and worked in the early Middle Ages and made a significant contribution to the development of Arabic grammar [5; 17-18].

The work "Mufassal" with its originality and scientific significance is of great importance not only for the development of scientific thought in the East, but also in the West. The English orientalist H.A.R. Gibb comments on this book: "There were very few works in Europe on Arabic studies that were as famous as Zamakhshari's "Mufassal", a textbook on the use of Arabic nahw and sarf ..." [6; 85-86]. Most European researchers, who began to study Arabic in the following centuries, made extensive use of this book of our compatriot.

Numerous reviews have been written by linguists on this work, which has great scientific value. According to German orientalist Karl Brockelmann, the number of commentaries on Mufassal is about thirty. One of the most famous commentaries is that of the medieval Syrian scholar Muwaffaqiddin abul Baqo Ya'ish 
Halabi, published in two volumes in Leipzig. Manuscripts and lithographs of the commentaries on the work are now kept in the libraries and collections of such cities as London, Berlin, Munich, Paris, Milan, Istanbul, Mashhad, Damascus, and Cairo [7; 509-510].

\section{RESULT AND DISCUSSIONS}

The Manuscripts Fund of the Institute of Oriental Studies named after Abu Rayhan Beruni of the Academy of Sciences of Uzbekistan contains 6 manuscripts of the work "Mufassal". The first of the manuscript copies of the work kept in the fund is the copy kept under inventory number 11459 [8]. This manuscript was copied by Qutbiddin Sherozi in $744 \mathrm{AH}$ (1343 AD) in Naskh script. This manuscript of the work, written in Arabic, consists of 155 sheets (310 pages). Compactly, this manuscript measures $12.5 \times 18 \mathrm{~cm}$. The number of lines on each page is 17. Each page of the manuscript has poygir (in the past, there were no page number on books and manuscripts, instead the last word of the previous page was given in the next page to find the order of pages in case the pages of the manuscript were scattered). In other words, it is marked with special footnotes peculiar to that time. The manuscript on the cardboard cover has been repaired. There are also places in the manuscript that were damaged by water, but did not spoil the text of the work. The text of the work is not tabular, there are a lot of comments and explanations around the text, that is, in the shape of very small frame around the text in the Nasta'liq script. It is even possible to see comments between lines of text.

The manuscript does not have a title page, it starts with an introduction. The introduction continued to page $3^{\mathrm{a}}$. In the introduction, the scholar Zamakhshari noted that this work consists of 4 parts: "Names", "Verbs", "Auxiliaries", and "Common Circumstances of the above".
From the sheet $3^{\mathrm{b}}$, the first part of the work, "Part of Names" begins with the following sentence: "The first part of the work is Part of Names" [8; $\left.3^{\mathrm{b}}\right]$

However, the names of the parts in the work are not separated from the text. Thus, the manuscript contains all four parts of the work, namely, "Names", "Verbs", "Auxiliaries", and "Common Circumstances of the above". They have a detail description of all the rules of nahw and sarf of the Arabic.

There is a note on page $154^{\mathrm{a}}$ of the manuscript which states the manuscript was copied in the year 744 After Hijrah [8; 154 ${ }^{\mathrm{a}}$ ]

Another manuscript copy of the scholar Zamakhshari's "Mufassal" is kept under inventory number $\mathbf{5 1 9 8}$ [9]. Its size is 222 sheets (444 pages), sized $15 \times 19 \mathrm{~cm}$, the number of lines on the page is 11. This manuscript has been restored.

This copy, copied in Naskh script, does not have a title page. It begins with the introduction to the work. In the margins of the introductory pages, which last up to page $4^{b}$, one can see the comments and explanations included in the scripts of Riqo, Naskh and Nasta'liq [9; $4^{\mathrm{b}}$ ]. The first part of the work, "Part of the Names", begins on page $5^{\mathrm{a}}$. The copying calligrapher did not separate the parts of the work in the manuscript, even the names of the parts were written in the same way as the text of the work. [9; $5^{\text {a }}$ ] It is therefore a bit difficult to distinguish them at a glance. To do this, the researcher must read the full text of the work. There is no end to the last fourth part of the work in the manuscript.

The manuscript of "Mufassal", stored under inventory number 3697, has a volume of 335 sheets (670 pages). The manuscript measures $25 \times 16 \mathrm{~cm}$ and has 23 lines per page. [10].

The pages of the manuscript have not been repaired, there are water stains on its initial pages, but the text is not damaged, they can be 
read. The manuscript is well preserved. The sheets have poygirs.

This manuscript does not have an introduction to the work and the initial pages of the Part of Names are missing. Later, when the cover of the manuscript was repaired, 2-3 pages were added to its introduction and a fihrist ( $a$ catalogue, table of contents) of the work was compiled and written on it. Based on this fihrist, the researcher can easily find the desired part of the work, even the necessary topic within the parts. For example, only the "Part of Names" itself is divided into topics such as gender category, agreements, adjective form of the verb, masdars (masdar means to edit, in this context masdars mean morphologically and syntactically changed forms of a word. In particular, it means changed forms of an infinitive form of a verb), singular form, dual form, plural form of the noun, and the pages of these topics are clearly indicated in the fihrist. According to it, on page 174 the sections "Verbs", on page 219 "Auxiliaries", on page 262 "Their common circumstances" begin. The calligrapher also gave the names of the parts, the topics in it, in slightly larger letters than the text of the work, and highlighted them. At the end of the fourth part, it is mentioned that this manuscript was copied in $768 \mathrm{AH} / 1367 \mathrm{AD}$.

Another manuscript copy of the work, kept under inventory number 5675, has a volume of 87 sheets (174 pages). The manuscript is compact, measuring $14.5 \times 18 \mathrm{~cm}$, and the number of lines on the page is 11 [11].

There are a lot of pages which need repairing in the manuscript, some pages are torn, some are pierced, and some pages have lines of text erased. The pages either have poygirs and or numbers.

This manuscript is not a complete copy. It begins with the introductory part of the work. After the introduction, the Names section is given. Even the Names section in the manuscript is not complete. From the conciseness of the manuscript, it can be concluded that only the first part of the work was intended to be given in this copy. The text in the Suls script does not have the harakāt (the script was a type of Arabic script which meant there should have been vowels, and in Arabic vowels are called harakat, it can be translated as motions). There are a lot of comments and explanations in the margins in Suls, Riqo and Nasta'liq scripts, some of which can be seen even between the lines.

The manuscript of "Mufassal", kept under inventory number 8972, measures $15 \times 22 \mathrm{~cm}$ and contains fragments of 3 different works [12]. The first 58 pages contain a part of Zamakhshari's "Mufassal”. Part of the work in the manuscript begins with the theme "Agreements" in the "Part of Names" and ends with the theme "Present Tense" in the "Part of Verbs". But in the passage in the folder the subject is not complete, in other words, the final pages are not there. The text is written in Nasta'liq script, there are not harakats, the number of lines on the page is 10. On some pages it is possible to see the comments and margins included in the Nasta'liq script.

This part of the manuscript needs repairing, some pages are torn, some are pierced, and some pages have lines of text erased. The sheets have poygirs.

The manuscript, kept under inventory number 3272, measures $17 \times 25.5 \mathrm{~cm}$. The volume contains certain parts of two different manuscripts of "Mufassal" [13]. The first book is given on the first 71 sheets of the volume. The work "Mufassal" begins with an introduction. From the page $2^{\mathrm{b}}$ on of the book, the "Parts of Names" begins, but this part is also not complete $\left[13 ; 2^{\mathrm{b}}\right]$. In this book, the text is given in 15 lines each page in Suls script; the letters in the text have harakats. In the book, the title of the section, as well as the names of the topics that make up the "Part of Names" are given in 
capital letters, slightly darker than the text of the work. This will help the reader to find the topic they want. There are a lot of comments and commentaries on the pages in different types of scripts. The sheets neither have poygirs nor numbers.

From page $72^{\mathrm{a}}$ of the volume begins a part of another manuscript of the work "Mufassal". The last pages of the "Part of Names" are provided here $\left[13 ; 72^{\mathrm{a}}\right]$. The second, third and fourth parts of the work are present in full. In this book, the names of the parts, the names of the topics in them are highlighted in capital letters in red ink. It is possible to see comments and explanations on some of its pages. The text in this book is also written in Suls script without harakats. There are not any poygirs on the pages, the sheets are not numbered. The number of lines on each page is 15 .

The last page of the book states that the manuscript was copied by Husayn ibn Hajji arRazi in $822 \mathrm{AH} / 1419 \mathrm{AD}$.

For a clearer view of the bibliographic information on the 6 manuscripts of the abovementioned work "Mufassal" available in the manuscript fund of the Institute of Oriental Studies named after Abu Rayhon Beruni of the Academy of Sciences of Uzbekistan, it is possible to refer to the table below.

Table 1

Bibliographic indexes of the manuscript copies of

The work "Mufassal"

Available in the manuscript fund of the Institute of Oriental Studies named after Abu Rayhon Beruni of the Academy of Sciences of Uzbekistan

\begin{tabular}{|c|c|c|c|c|c|}
\hline № & $\begin{array}{c}\text { Inventory } \\
\text { number }\end{array}$ & $\begin{array}{c}\text { The year } \\
\text { manuscript } \\
\text { was copied }\end{array}$ & The name of the calligrapher & $\begin{array}{c}\text { Number } \\
\text { of } \\
\text { sheets }\end{array}$ & $\begin{array}{l}\text { Size of the } \\
\text { manuscript } \\
\text { (in } \mathrm{cm})\end{array}$ \\
\hline 1. & 11459 & $744 / 1343$ & Kutbiddn Sheraziy & 155 & $12,5 \times 18$ \\
\hline 2. & 5198 & $\begin{array}{c}\text { Not } \\
\text { applicable }\end{array}$ & Not applicable & 222 & $15 \times 19$ \\
\hline 3. & 3697 & $768 / 1367$ & Not applicable & 335 & $25 \times 16$ \\
\hline 4. & 5675 & $\begin{array}{c}\text { Not } \\
\text { applicable }\end{array}$ & Not applicable & 87 & $14,5 \times 18$ \\
\hline 5. & 8972 & $\begin{array}{c}\text { Not } \\
\text { applicable }\end{array}$ & Not applicable & 58 & $15 \times 22$ \\
\hline 6. & 3272 & $822 / 1419$ & Husayin ibn Hoji ar-Rozi & 71 & $17 \times 25,5$ \\
\hline
\end{tabular}

As for the lithographs of the work "Mufassal", the Manuscripts Fund of the Institute of Oriental Studies named after Abu Rayhon Beruni of the Academy of Sciences of
Uzbekistan stores two lithographs under inventory numbers $\mathbf{1 1 3 2 9}$ and 12492.

Of these, the lithograph which is kept under inventory number 11329 was published in 1903 
in Lucknow by Abdu-I-Ali Madrasi. This lithography with a cardboard cover is well preserved. The size is $24 \times 15 \mathrm{~cm}$, the total size is 255 pages [14].

There are two works in this lithography copy, the first of which is Mahmud Zamakhshari's "Mufassal" and the second is Ibn Sina Bukhari's "at-Taqsim fi-l-ulumi-l-aqliya". Most of the lithography, in other words, 248 out of 255 pages, is "Mufassal". The lithograph has a 12page introductory section provided by the publisher before the work starts. It contains information about Zamakhshari's personality, biography, and way of life, teachers and students. In addition, the scientific activity of Zamakhshari is widely analyzed. Along with his scientific works, the lithography also speaks about the divans he created in poetry. The special table lists 30 works that make up the scientific heritage of Zamakhshari. After that, the work "Mufassal" and its significance were discussed. The contents of the work are also presented in the form of a special table on two pages. The next page contains the title page of the work, which contains the name of the work, its author, publisher, year and place of publication. The work begins on the next page. The text of the work is printed into a special frame, in a beautiful Naskh script. Most of the text does not have harakats. The chapters and sections of the work are given in capital letters; they are given in bold which highlights them from the text.

The margins of the page are also taken into a special frame, within which the comments on the work are given around the text. On some pages, comments are given in the text, that is, between lines of text. The text of the comments is printed in very small letters. This makes it a little harder to read.
Another lithography copy of the work is kept under inventory number 12492. It was published in $1323 \mathrm{AH} / 1905$ by the Egyptian Taqdim Publishing House. The size of the lithography is $17 \times 25 \mathrm{~cm}$ [15]. It contains 4 works, the first of which is "Mufassal". Lithography publisher is Muhammad Amin Khanji. In the title page of the work, based on the work of Kotib Chalabi "Kashfu-z-zunun", the publisher gave information about when Zamakhshari wrote this work.

The lithography copy's pages are not overly decorated. Even the chapters and sections of the work are difficult to distinguish at a glance. They are not visible at a glance because they are given in small embossed brackets. At the top of the page is the text of the work in slightly larger letters, and at the bottom in smaller letters is a commentary on the work by Said Muhammad Badriddin Halabi. On some pages it can be seen that the volume of the commentary given to it is much larger than the text of the work. Comments were given through special footnotes. On the last pages 406-408 of the work there is a fihrist of the work "Mufassal".

\section{CONCLUSION}

It is clear from the above considerations about the work that Zamakhshari's work "al-Mufassal fi san'ati-l-i'rob" was widespread at times and it was famous both in the East and West. In addition, the fact that the Arabs learned the rules of their native language with the help of the work of our compatriot testifies to the fact that Zamakhshari had a unique intellect. 


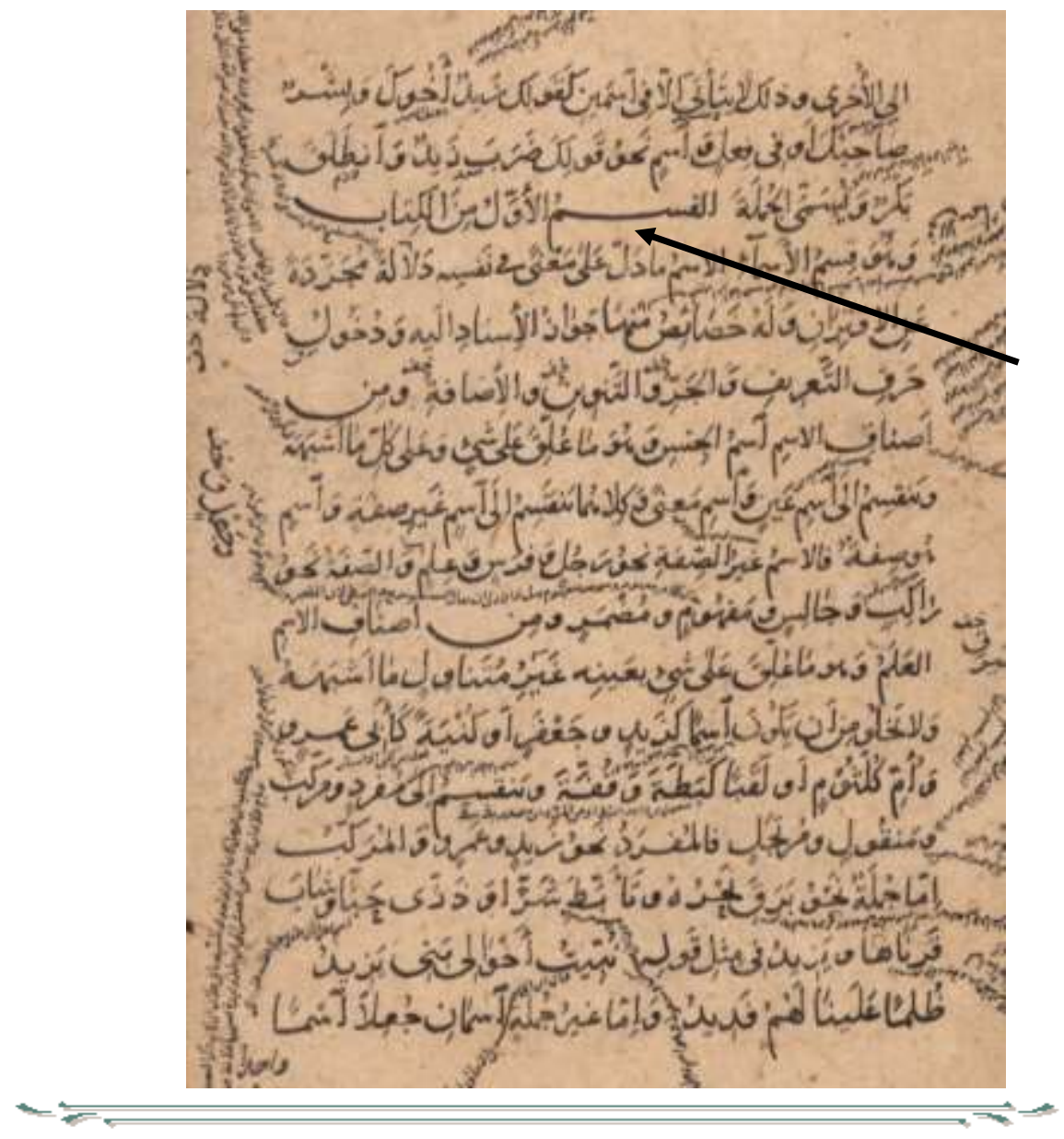

$1^{\text {st }}$ illustration. Page $3^{B}$ of the manuscript of the work "Mufassal" kept under inventory number 11459. The manuscript does not have a title page, it starts with an introduction. The introduction continued to page $3^{a}$. From page $3^{b}$ in the picture, the first part of the work, the Part of Names, begins with the following sentence:

\section{القسم الاول من الكتاب و هو قسم الاسماء}

\section{"The first part of the work is the Part of Names"}

\section{REFERENCES}

1. Xalidov B.Z. Zamaxshari // Semitskiye yaziki. Vipusk 2 (ch. 2). - Moscow: Nauka, 1965.

2. Ibn Xallikon. Vafoyotu-I-a'yon va anbo' abno'i-z-zamon. J. 1. - Egypt: 1881.

3. Abdujabborov A. Arab tili. - Tashkent: Tashkent University of Islam, 2007.

4. Abu-I-Qosim Mahmud az-Zamaxshariy. Nozik iboralar (The author of commentary and translation is Ubaydulla Uvatov). Tashkent: Kamalak, 1992.

5. Az-Zamaxshari. Asa:su-l-baloga. - Beyrut: Daru-l-kutubi-I-ilmiyya. - 1998.

6. Gibb X. A. R. Arabskaya literatura. Klassicheskiy period (Perevod A. B. Xalidova). - Moscow Vostochnaya literatura, 1960.

7. Brockelmann C. Geschichte der arabischen litteratur. Bd. I. - Leiden, 1937. 
8. Zamaxshari. Al-Mufassal fi san'ati-l-i'rob. Manuscript. Manuscript Fund of the Institute of Oriental Studies named after Abu Rayhon Beruni of the Academy of Sciences of Uzbekistan. 11459 inventory number.

9. Zamaxshari. Al-Mufassal fi san'ati-l-i'rob. Manuscript. Manuscript Fund of the Institute of Oriental Studies named after Abu Rayhon Beruni of the Academy of Sciences of Uzbekistan. 5198 inventory number.

10. Zamaxshari. Al-Mufassal fi san'ati-l-i'rob. Manuscript. Manuscript Fund of the Institute of Oriental Studies named after Abu Rayhon Beruni of the Academy of Sciences of Uzbekistan. 3697 inventory number.

11. Zamaxshari. Al-Mufassal fi san'ati-l-i'rob. Manuscript. Manuscript Fund of the Institute of Oriental Studies named after Abu Rayhon Beruni of the Academy of Sciences of Uzbekistan. 5675 inventory number.

12. Zamaxshari. Al-Mufassal fi san'ati-l-i'rob. Manuscript. Manuscript Fund of the Institute of Oriental Studies named after Abu Rayhon Beruni of the Academy of Sciences of Uzbekistan. 8972 inventory number.

13. Zamaxshari. Al-Mufassal fi san'ati-l-i'rob. Manuscript. Manuscript Fund of the Institute of Oriental Studies named after Abu Rayhon Beruni of the Academy of Sciences of Uzbekistan. 3272 inventory number.

14. Zamaxshari. Al-Mufassal fi san'ati-l-i'rob. Manuscript. Manuscript Fund of the Institute of Oriental Studies named after Abu Rayhon Beruni of the Academy of Sciences of Uzbekistan. 11329 inventory number.

15. Zamaxshari. Al-Mufassal fi san'ati-l-i'rob. Manuscript. Manuscript Fund of the Institute of Oriental Studies named after Abu Rayhon Beruni of the Academy of
Sciences of Uzbekistan. 12492 inventory number. 